This article has been accepted for publication by Journal of Anatomy (Anatomical society of Great Britain and Ireland; Blackwell Publishing Ltd.) and is provided here as a manuscript preprint as allowed by the copyright licence form. No redistribution of this document is permitted by third parties. Copyright (c) 2007 by the authors.

\title{
The functional development of Leydig cells in a marsupial.
}

\author{
Christopher M. Butler, ${ }^{1}$ Geoff Shaw, Joan Clark, and Marilyn B. Renfree ${ }^{2}$ \\ Department of Zoology, University of Melbourne, Victoria 3010, Australia. \\ ${ }^{1}$ Present address: Monash University Centre for Cancer Research, Monash Institute \\ of Medical Research, Monash Medical Centre, Clayton, Victoria 3168, Australia
}

${ }^{2}$ Corresponding author:

Email: m.renfree@,zoology.unimelb.edu.au Tel.: +61 383444376 Fax: +61 39348 1719 


\section{Summary:}

Leydig cells are the major source of androgen in the male mammal. We describe here for the first time the development of the Leydig cell in a macropodid marsupial, the tammar wallaby, Macropus eugenii. Leydig cells are first recognized morphologically two days after birth with the appearance of lipid droplets in the cytoplasm of certain interstitial cells. Lipid content closely matches the steroid content of the developing testis and marks the maturation of the steroid synthesis pathway in the tammar testis. Morphologically mature Leydig cells, marked by distinct mitochondria with tubular cristae and an extensive anastomosing network of smooth endoplasmic reticulum, are developed by day 10 after birth - the time of peak testosterone content in peri-natal tammar testes. The volume percentage of each cell type in the testis does not change over time so the growth of each cellular component keeps pace with growth of the whole testis. There was no morphological or quantitative evidence of a change from one population of Leydig cells to another in the tammar testis as has been reported in several other species including the rat, mouse and human. Maturation of the testis is also marked by the development of tight junctions between the cell membranes of adjacent Sertoli cells. These appear around day 30 after birth and coincide with the onset of mitotic arrest in male germ cells. Overall, the development of the Leydig cell in the tammar wallaby follows a similar pattern to that seen in other mammals, although the start of Leydig cell differentiation is, like many other organ systems in marsupials, post-natal, not fetal and there appears to be only a single population of Leydig cells.

Keywords: tammar wallaby, ultrastructure, testis, tight junction, morphometry, germ cell 


\section{Introduction}

The Leydig cells of the testis synthesise androgens and this steroidogenic activity is reflected in the cellular ultrastructure (Zirkin et al., 1980, Ewing and Zirkin, 1983) . Initially, prospective Leydig cells are undifferentiated mesenchymal cells with oval to irregular dark-staining nuclei and little cytoplasm. Progressive development of the Leydig cell is marked by an increase in the amount of cytoplasm and the development of organelles characteristic of steroid producing cells i.e. large numbers of mitochondria displaying tubular cristae; extensive smooth (agranular) endoplasmic reticulum (SER); some rough (granular) endoplasmic reticulum (RER) and darkstaining cytoplasm (Byskov, 1986, de Kretser and Kerr, 1988). Associated with this is the appearance of abundant lipid in the cytoplasm as distinct electron-dense droplets (Zirkin et al., 1980, Huhtaniemi and Pelliniemi, 1992). As the cells mature lipid content drops and SER increases. Mature fetal and adult Leydig cells contain few lipid droplets and the SER is an extensive anastomosing network of tubules throughout the cytoplasm (Benton et al., 1995). This pattern of Leydig cell morphology has been described in a number of mammalian species (Fawcett and Burgos, 1960, Gondos et al., 1974, Sinha et al., 1977, Wing and Lin, 1977).

There are thought to be two distinct populations of Leydig cells, fetal and adult, that arise at different times during the development of the testis (Lording and De Kretser, 1972, Huhtaniemi and Pelliniemi, 1992). The fetal population produces androgens at the crucial time for virilization of the urogenital system and external genitalia. Fetaltype Leydig cells are thought to degenerate or dedifferentiate soon after morphogenesis of the male sex tract is complete (Byskov et al., 1983, Kuopio et al., 1989, Hardy et al., 1991), although fetal Leydig cells may persist into the adult testis becoming a small minority in the adult population (Kerr and Knell, 1988). The adult 
population, appearing at or just before puberty, is responsible for spermatogenesis and the maintenance of male secondary sex characters (de Kretser and Kerr, 1988). In some species such as the human, the two populations of Leydig cells can be easily distinguished by their temporal separation, but in other animals, particularly the rodents, they are not distinct from one another and the populations overlap (Kerr and Knell, 1988, Lording and De Kretser, 1972).

In marsupials, differentiation of the testis is a perinatal to postnatal event. In the bandicoots, the Eastern quoll (Dasyurus viverrinus) and the brown marsupial mouse (Antechinus stuartii), the testis differentiates a few days after birth (Ullmann, 1981, Ullmann, 1984, Taggart et al., 1993). In the grey opossum (Monodelphis domestica) and the brushtail possum (Trichosurus vulpecula), the testis differentiates perinatally (Maitland and Ullmann, 1993, Ullmann, 1993, Xie et al., 1996), as in the tammar wallaby (Macropus eugenii) (Renfree et al., 1992a, Renfree et al., 1995, Renfree et al., 1996, Renfree, 1994). In Monodelphis domestica, there is only one population of Leydig cells that continue to function through puberty and into adult Leydig cells (Xie et al., 1996). Thus, there is no separation between early and adult Leydig cells in this marsupial. In contrast, in the dasyurid marsupial, Antechinus stuartii, there may be two populations of Leydig cells (Taggart et al., 1993). In this marsupial, Leydig cells are largely lost from the interstitium of testis before puberty and reappear at maturity. Peritubular clusters of Leydig cells are thought to be the source of the renewed interstitial population and this may represent a separate adult Leydig cell population (Taggart et al., 1993).

The timing of morphological differentiation of the Leydig cell and its temporal relationship with steroidogenic activity is unknown in the tammar. Testicular androgens in the tammar are elevated from about day 2 of pouch life and reach a 
maximum by day 10 (Renfree et al., 1992b). Testosterone remains high until day 40 after which it drops to basal levels by day 70, covering the period when male phenotypic characters are forming (Renfree et al., 1992b, Renfree et al., 1996). Surprisingly, concentrations of circulating plasma testosterone do not differ between males and females (Wilson et al., 1999), but a metabolite of testosterone, $5 \alpha-$

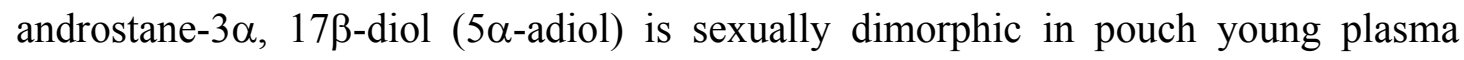
(Shaw et al., 2000). 5 $\alpha$-adiol is converted into dihydrotestosterone in the urogenital sinus and urogenital tubercle of male pouch young and administration of $5 \alpha$-adiol to female pouch young virilizes the urogenital tract (Leihy et al., 2002, Shaw et al., 2000, Leihy et al., 2001). 5 $\alpha$-adiol is thus the circulating androgen responsible for virilization in the tammar (Leihy et al., 2001, Wilson et al., 2003, Shaw et al., 2000, Renfree et al., 2006).

The establishment of the blood/testis barrier is a critical event in testicular development and requires the formation of tight junctions between Sertoli cells of the testis. As with other aspects of male development, tight junction formation is regulated by androgens which also regulate the permeability of the blood-testis barrier influencing germ cell differentiation (Meng et al., 2005). This study therefore describes the morphogenesis of Leydig cells in the differentiating male tammar gonad at the ultrastructural level, correlates this with the development of internal organelles and androgen production in the testis and describes the timing of tight junction formation in the tammar testis.

\section{Methods}

Animals 
Tammar wallabies of Kangaroo Island (South Australia) origin were housed in grassy paddocks in our breeding colony in Victoria, Australia. The grass was supplemented with oats, lucerne cubes, fresh vegetables and water ad libitum. Care and treatment of animals conformed to the National Health and Medical Research Council of Australia guidelines (1997), and all experimental work was approved by Animal Experimentation Ethics Committees at the University of Melbourne. Pouch young were aged either from the known day of birth or by the use of head length tables (Poole et al., 1991). Small pouch young were killed by decapitation, and older pouch young, peri-pubertal and adult males were killed by injection of sodium pentobarbitone $(150 \mathrm{mg} / \mathrm{kg})$ in sterile saline.

\section{Electron microscopy}

Gonads of pouch young less than ten days old were removed and immersed in Superfix fixative (3\% paraformaldehyde, $0.15 \%$ picric acid, $2 \%$ glutaraldehyde in 0.2M sodium cacodylate buffer; $\mathrm{pH} 7.4$ ) for electron microscopy and fixed overnight. With older animals $1 \mathrm{~mm}^{3}$ pieces of gonad were fixed overnight. Tissue pieces were then washed in cacodylate buffer, post-fixed in $1 \%$ osmium tetroxide, dehydrated in ascending concentrations of alcohol and embedded in Spurr's resin (Probing and Structure, Melbourne, Australia).

Semi-thin sections were cut with glass knives on a Reichert-Jung Ultracut $\mathrm{S}$ ultramicrotome, stained with toluidine blue and examined with a light microscope. Areas of interest containing putative Leydig cells were identified by their dark cytoplasm and position (intertubular). Thin sections of these areas were then cut with a diamond knife on the ultramicrotome, mounted on copper grids and stained with uranyl acetate $(5 \mathrm{~min})$ and lead citrate $(10 \mathrm{~min})$. Grids were viewed and photographed with a Phillips-CM 100 transmission electron microscope. 


\section{Light microscopy}

Testes were fixed in Bouin's fixative overnight, washed in several changes of ethanol, processed and embedded in wax. Serial sections were cut at $8 \mu \mathrm{m}$, mounted on glass slides, dewaxed and stained with Harris's haemotoxylin and eosin.

\section{Quantitation}

Volume of testes was estimated by Cavalieri's method (Gundersen et al., 1988) using computer-assisted software: Castgrid software (Olympus Danmark A/S, Albertslund, Denmark). In each section 25 points in 10 fields were counted. The type of cell (Sertoli, germ cell, Leydig cell or interstitial cell) at each sample point was assessed and counted. The average number of points per section for each cell type was calculated and multiplied by the area of each sample point and the length of testis to give a volume of the testis for each cell type (Silva and Merzel, 2001). This was then divided by the calculated testis volume to give a percentage volume of testis for each cell type.

\section{Results}

Day 0

On the day of birth the tammar testis was beginning to show signs of differentiation of the major testicular cell types. The mesenchymal cells of the interstitium were undifferentiated with a fibroblastic appearance with irregularly shaped nuclei and little cytoplasm so the large nucleus dominated the cell. The nucleus to cytoplasm ratio was approximately $3: 1$. Occasional cells showed signs of cytoplasmic expansion. Interstitial cells did not fill the entire interstitial space and there was abundant lymph space between cells (Fig 1a). Mitochondria were common in the very granular 
cytoplasm with abundant ribosomes. There was little SER and no lipid inclusions visible. There was a close association of RER and mitochondria occurring in many cells (not shown). Sertoli cells were loosely arranged in tubules in some, but not all, animals (Fig. 1a) and were well developed with typical oval to round basal nuclei closely adhered to one another. The developing seminiferous tubules were occasionally enclosed by fibroblastic peritubular/myoid cells aligned abutting the tubules. A basal lamina was starting to form but was patchy and did not completely enclose the tubule. The tubules enclosed germ cells that were situated near the centre of tubules but there was no tubular lumen.

Day 2

Day 2 marked the first time that cells with the distinct morphological markers of steroid producing organelles appeared in the developing testis. The tubules of Sertoli cells were well formed and distinct. The basal lamina was still poorly formed and there were associated peritubular cells (Fig 1b). A tunica albuginea could be seen forming in the periphery of the gonad where arrays of fibroblastic cells were aligning parallel to the surface epithelium.

Leydig cells occurred in clusters or 'nests' of dark-staining cells with highly granular electron-dense cytoplasm scattered throughout the interstitium. The cytoplasm enlarged in these cells and was marked by abundant lipid inclusions. The nuclear:cytoplasmic ratio was approximately 1.5:1 (Fig. 1c). Mitochondria were again abundant with the tubular cristae typical of these organelles in steroid-producing cells. SER was expanding in these cells and vesicles were common but it was not particularly extensive. Mitochondria were frequently associated with RER, although 
less commonly than in day 0 testes (Fig. 1d). Mitochondria were more common in cells that had no lipid inclusions but the two were not mutually exclusive.

Day 6

By day 6, clusters of interstitial Leydig cells similar to those seen at day 2 were more common (Fig. 2a). Lipid droplets were present in some cells but much less commonly than the abundant inclusions of day 2 Leydig cells. Mitochondria, which were large, elongated in shape with a round cross-section and tubular cristae, were abundant and clustered to one end of the cell. They were associated with both smooth and rough ER and RER-mitochondrial complexes were common (Fig. 2b). Development of RER was still extensive and abundant ribosomes occur throughout the cytoplasm of these cells. The SER was beginning to expand. The plasmalemma of these cells had long filopodial extensions and these often overlapped with neighbouring cells (Fig. 2b). There was an increase in cell size due to the increased amount of cytoplasm so that nuclear:cytoplasmic ratio was $1: 1$

Day $10-11.5$

By day 10 the Leydig cells were typically dark-staining with large, oval to irregularlyshaped nuclei and typical organelles of mature steroid producing cells (Fig. 2, c and d). The Leydig cells were marked by extensive mitochondrial development; vesicles; granular, dark-staining cytoplasm and virtually no lipid inclusions. The cells were larger than those seen at earlier stages and had a nuclear:cytoplasmic ratio of approximately 1.5:1. Mitochondria were extremely abundant and had the form typical of steroid producing cells. Lipid was rare in these cells which were clustered and often closely adjoining (Fig. 2c) but there was still an extensive non-cellular component to the interstitium surrounding them (Fig. 2c). SER was well developed and often 
associated with an extensive Golgi apparatus somewhat obscured by the extremely granular appearance of the cytoplasm (Fig. 2d).

Day 21-36

These cells were similar to those seen at day 10. They were often paired or grouped and frequently associated with blood vessels. Golgi apparatus were common (Fig. 3a). These Leydig cells often had long filopodial strands of cytoplasm extending around one another (Fig. 3b). By day 30 the SER was very extensive, packed into the cells in concentric layers (Fig. 3c). Nuclei often have a folded appearance or were bi-lobed. RER, which was commonly seen in cells before day 10 was not often seen in these older cells. Lipid was occasionally present.

Day 54 - 164

Later in development Leydig cells were present in groups. There was still much fluidfilled space between groups of cells and mesenchymal, undifferentiated cells were common. The cytoplasm and general appearance of the Leydig cells was similar to that seen from day 10 with extensive development of SER and Golgi bodies. Extracellular collagen occurred in the interstitial space probably laid down by fibroblastic cells derived from the undifferentiated mesenchyme (Fig. 3d). Leydig cells were present as scattered clusters in the testis including peritubular and interstitial cells. SER was often arranged in tightly packed parallel arrays (Fig. 4a). Lipid droplets were abundantly present in some cells though not in all. Occasional undifferentiated mesenchymal cells were also seen.

Day 275-320

At this stage of their development tammar pouch young are fully furred and ready for weaning and pouch exit. There were no noticeable differences between the testes of 
pouch young examined between days 275 (approximately 9 months) and 320 days (11 months). In these older testes intercellular space was much reduced with most of the interstitium filled by Leydig cells with occasional mesenchymal/fibroblastic cells. Peritubular Leydig cells were common. As with days 54 to 164 there was extensive development of the SER with abundant mitochondria, cells often had small filopodia extending from the plasmalemma and lipid droplets were frequently present (Fig. 4b). The SER appeared as anastomosing vesicles or parallel arrays depending on the orientiation of the section (Fig. 4c). There were no signs of spermatogenesis.

\section{Peri-pubertal specimens (13 months and 24 months)}

At 13 months the tammar testis is still immature. The tubules showed no signs of spermatogenesis with generalized germ cells present but no spermatogonia. Leydig cells in these testes were identical with those found after day 40 p.p. The presence of abundant lipid inclusions highlights the immature sexual status of the animal at this age (Figure 4d). In contrast at 24 months the testis was fully mature with spermatogonia and mature sperm present in the tubules (see light micrograph Figure 20f), and the Leydig cells had an adult morphology (Figure 5a). However, the distribution of other cells in the testis was similar in pre- and post-pubertal animals. There was no evidence for a second population of Leydig cells and there appeared to be a continuous transition from immature to mature Leydig cells originating from within a single interstitial population.

\section{Adult testis}

In the adult testis (Fig.5b), Leydig cells filled most of the interstitium with little intercellular space between the seminiferous tubules. The Leydig cells typically had rounded to oval nuclei and there was an extremely SER-rich cytoplasm. Leydig cells 
were distinguished from other interstitial and peritubular cells by their darker staining cytoplasm. They were frequently clustered tightly together in groups which had interdigitating membranes (Fig. 5b). Lipid was rarely present in these cells. Spermatogenesis was occurring within the functional seminiferous tubules.

\section{Stereology and light microscopy}

Testis volume increased exponentially between day 10 and day 100 and then the rate of exponential increase slowed (Fig. 6). There were no notable changes in percentage volume of Leydig, Sertoli and interstitial cells with age until after puberty (Fig. 7). The percentage germ cell content of the testis increased between day 10 and day 30 and then remained at this higher level at older ages. Post-puberty there was a marked increase in cells of germ cell origin, the spermatogonia, showing active spermatogenesis had been established. There was no marked change in Leydig cell content of the testes over this time which strongly suggests that there was a single population developed that continued to be present at all ages. The steady state in Leydig cell content of the testis from day 10 onwards also coincided with the maturation of the ultrastructure of the Leydig cell seen by day 10 of pouch life.

\section{Sertoli cell tight junctions}

Tight junctions first appeared on the cell membranes of adjacent Sertoli cells close to the basally-located nucleus at the periphery of the seminiferous tubule at day 31 of pouch life (Fig. 8). Tight junctions occurred in all older stages examined.

\section{Discussion}

The pattern of Leydig cell differentiation in the tammar testis closely follows that seen in eutherian mammals and differs only with respect to the timing. Leydig cells in the tammar wallaby can first be unambiguously identified at day 2 p.p. as interstitial cells 
that are marked by an accumulation of lipid inclusions. They are derived from undifferentiated mesenchymal cells of the testis interstitium. Some of these mesenchymal cells become putative Leydig cells, while others form peritubular myoid cells, fibroblasts and the cells of the tunica albuginea.

There is a progressive increase in overall Leydig cell size brought about by an increasing nuclear-cytoplasmic ratio, changing from approximately $3: 1$ in the undifferentiated mesenchymal cells at day 0 p.p. to 1:5 in the adult Leydig cell. As the cells develop the number of mitochondria, and particularly the amount of smooth endoplasmic reticulum, gradually increase. The increase in cell size is accompanied by an overall increase in interstitial cell abundance. Lipid accumulation is common in early or developing Leydig cells in both fetal and pubertal populations (Lording and De Kretser, 1972, Gondos et al., 1974, Sinha et al., 1977, Huhtaniemi and Pelliniemi, 1992) probably as a result of immature or inactive androgen synthetic pathways. There is accumulation of lipid in the non-breeding season in the testes of species that have seasonally regressing testes (Sinha et al., 1977, Tahka, 1988) and in developing fetal or neonatal Leydig cells (Van Vorstenbosch et al., 1984, Nistal et al., 1986, Codesal et al., 1990, Prince, 1990). In the tammar, lipid content of Leydig cells initially increases but drops away towards day 10 p.p. and reappears in older pouch young ( $>$ day 60 p.p.), coinciding with the elevated testosterone between days 10 and 45 (Renfree et al., 1992b). Testicular androgen then remains low until puberty, which occurs between 18 and 24 months of age in this species (Renfree et al., 1992b, Williamson et al., 1990). Similarly, the lipid content of pre-pubertal Leydig cells is high. Lipid droplets are rare in the adult Leydig cell. The abundance of lipid in Leydig cells of the developing tammar testis is therefore inversely proportional to testosterone levels in the testis. 
Leydig cells of the tammar testis have extensive dark-staining cytoplasm containing abundant mitochondria with the tubular cristae typical of steroid producing cells. The SER becomes well developed by day 10 and continues to develop to even greater prominence in Leydig cells of older testes. SER and testosterone production are strongly correlated (Zirkin et al., 1980) and in the adult tammar Leydig cell SER is the most highly developed. However, despite extensive SER development in Leydig cells of late pouch young testes (day 100 - 309 p.p.), the presence of abundant lipid in these cells suggests that the steroidogenic enzyme pathway is not fully functional.

The function of the unusual RER/mitochondrial complexes in the early Leydig cell is not clear. Similar complexes have been noted in the peritubular Leydig cells of differentiating fetal pig testes (Van Vorstenbosch et al., 1984) and in the differentiating mesenchymal cells of the hamster testis (Gondos et al., 1974). Likewise in the tammar they occur at an early stage when the putative Leydig cells are beginning to enlarge and differentiate. The active cytoplasmic expansion of these cells suggests increased protein production requiring mitochondrial activity which may explain the close association between these organelles.

There was an increase in germ cell content of the testis between day 10 and day 30 p.p. as a consequence of germ cell proliferation. Increased germ cell content is a likely consequence of the peak of the first wave of M-spermatogonial mitosis which in the tammar peaks at day 20 p.p. at this time. Sertoli cell tight junctions, essential for the establishment of the blood/testis barrier, are present by day 31 of pouch life which coincides with the onset of mitotic arrest (D. O'Brien, G. Shaw and M.B Renfree; unpublished observations). Post-puberty there is a large increase in germ cell content of the testis (spermatogonia and mature spermatids) that indicates spermatogenesis has been established. 
In the rat, adult Leydig cells may be distinguished from fetal cells by low lipid content, larger size, a tendency to form aggregates and an irregular cell shape with filopodial extensions (Zirking and Ewing, 1987; Kerr and Knell, 1988). In tammars distinct subpopulations of Leydig cells could not be distinguished by these criteria Initially the interstitium of the developing tammar testis contained only scattered undifferentiated cells but as differentiation proceeded the interstitium became filled with cells. These were mostly maturing Leydig cells but with scattered fibroblastic and undifferentiated mesenchymal cells. This suggests that there is a gradual transition to adult (or mature) Leydig cells from earlier populations as has been described in Monodelphis domestica (Xie et al., 1996). In the dasyurid Antechinus stuartii, there are two phases of development. Early Leydig cells are derived, as in Monodelphis and the tammar, from differentiating mesenchymal cells of the testis interstitium and fill the space between the testis cords but regress in the testis before puberty. There are peritubular clusters of cells in the early testis that remain after most of the early Leydig cells have regressed and are thought to be the source of the adult Leydig cells at puberty (Taggart et al., (1993). We did not observe any unique clusters of peritubular cells in the tammar and were not able to distinguish Leydig cells at the periphery from those found in other parts of the interstitium. We also did not observe any period when Leydig cells regressed in the developing testis in the tammar. There was no marked change in appearance or abundance of Leydig cells which remained clearly immature as late as 13 months in peri-pubertal testes and consisted of only one population of Leydig cells with either abundant lipid pre-pubertally or a mature adult Leydig cell morphology post-pubertally. We conclude that in tammars, as in Monodelphis but not in Antechinus, there is only one population of Leydig cells from which the adult population in directly derived. Thus, while Leydig cell differentiation 
in the tammar follows a broadly similar pattern to that established for other eutherian and marsupial mammals, there is no evidence of a biphasic origin of Leydig cells.

\section{Acknowledgements}

We thank Dr. Deanne Whitworth, Dr. Michael Leihy, Anne Duns and Richard Moyle for assistance in animal handling and tissue collection and Mr. Bruce Abaloz for help with histology. We thank Professor J.D. Wilson for helpful discussions throughout this study. Animals were held under permit number RP-92-099 from the Department of Conservation and Natural Resources, Victoria, Australia. This study was supported by an Australian National Health and Medical Research Council grant to Marilyn Renfree, Geoffrey Shaw and Roger Short.

\section{Literature cited}

Benton, L., Shan, L. X. \& Hardy, M. P. (1995) Differentiation of adult Leydig cells. J Steroid Biochem Mol Biol, 53, 61-8.

Byskov, A., Andersen, C. \& Westergaard, L. (1983) Dependence of the onset of meiosis on the internal organization of the gonad. In McLaren, A. \& Wylie, C. C. (Eds.) Current Problems in Germ Cell Differentiation.

Byskov, A. G. (1986) Differentiation of mammalian embryonic gonad. Physiol Rev, $66,71-117$.

Codesal, J., Regadera, J., Nistal, M., Regadera-Sejas, J. \& Paniagua, R. (1990) Involution of human fetal Leydig cells. An immunohistochemical, ultrastructural and quantitative study. J Anat, 172, 103-114.

de Kretser, D. M. \& Kerr, J. B. (1988) The Cytology of the Testis. In Knobil, E., Neill, J. \& al, e. (Eds.) The Physiology of Reproduction. New York, Raven Press, Ltd.

Ewing, L. \& Zirkin, B. (1983) Leydig cell structure and steroidogenic function. Recent Prog Horm Res, 39, 599-635.

Fawcett, D. \& Burgos, M. (1960) Studies on the fine structure of the mammalian testis. II. The human interstitial tissue. Am J Anat, 107, 245-269.

Gondos, B., Paup, D., Ross, J. \& Gorski, R. (1974) Ultrastructural differentiation of Leydig cells in the fetal and postnatal hamster testis. Anat Rec, 178, 551-566. 
Gundersen, H. J., Bagger, P., Bendtsen, T. F., Evans, S. M., Korbo, L., Marcussen, N., Moller, A., Nielsen, K., Nyengaard, J. R., Pakkenberg, B. \& et al. (1988) The new stereological tools: dissector, fractionator, nucleator and point sampled intercepts and their use in pathological research and diagnosis. Apmis, 96, 857-81.

Hardy, M., Gelber, S., Zhou, Z., Penning, T., Ricigliano, J., Ganjam, V., Nonneman, D. \& Ewing, L. (1991) Hormonal control of Leydig cell differentiation. Ann N Y Acad Sci, 637, 152-163.

Huhtaniemi, I. \& Pelliniemi, L. (1992) Fetal Leydig cells: cellular origin, morphology, life span, and special functional features. Proc Soc Exp Biol Med, 201, 125-140.

Kerr, J. B. \& Knell, C. M. (1988) The fate of fetal Leydig cells during the development of the fetal and postnatal rat testis. Development, 103, 535-44.

Kuopio, T., Tapanainen, J., Pelliniemi, L. \& Huhtaniemi, I. (1989) Developmental stages of fetal-type Leydig cells in prepubertal rats. Development, 107, 213220.

Leihy, M. W., Shaw, G., Renfree, M. B. \& Wilson, J. D. (2002) Administration of $5 \alpha$-androstane-3 $\alpha, 17 \beta$-diol to female tammar wallaby pouch young causes development of a mature prostate and male urethra. Endocrinology, 143, 264351.

Leihy, M. W., Shaw, G., Wilson, J. D. \& Renfree, M. B. (2001) Virilization of the urogenital sinus of the tammar wallaby is not unique to $5 \alpha$-androstane- $3 \alpha, 17 \beta$ diol. Mol Cell Endocrinol, 181, 111-5.

Lording, D. \& De Kretser, D. (1972) Comparative ultrastructural and histochemical studies of the interstitial cells of the rat testis during fetal and postnatal development. J Reprod Fertil, 29, 261-269.

Maitland, P. \& Ullmann, S. (1993) Gonadal development in the opossum, Monodelphis domestica: the rete ovarii does not contribute to the steroidogenic tissues. J Anat, 183, 43-56.

Meng, J., Holdcraft, R. W., Shima, J. E., Griswold, M. D. \& Braun, R. E. (2005) Androgens regulate the permeability of the blood-testis barrier. Proc Natl Acad Sci U S A, 102, 16696-700.

Nistal, M., Paniagua, R., Regadera, J., Santamaria, L. \& Amat, P. (1986) A quantitative study of human Leydig cells from birth to adulthood. Cell Tissue Res, 246, 229-236.

Poole, W., Simms, N., Wood, J. \& Lubulwa, M. (1991) Tables for age determination of the Kangaroo Island Wallaby (Tammar), Macropus eugenii, from body measurements. CSIRO, Division of Wildlife and Ecology, Canberra.

Prince, F. (1990) Ultrastructural evidence of mature Leydig cells and Leydig cell regression in the neonatal human testis. Anat Rec, 228, 405-417.

Renfree, M. (1994) Sexual dimorphisms in the gonads and reproductive tracts of marsupial mammals. In Short, R. \& Balaban, E. (Eds.) The Differences Between the Sexes. Cambridge, Cambridge University Press.

Renfree, M., Harry, J. \& Shaw, G. (1995) The marsupial male: a role model for sexual development. Phil Trans $R$ Soc Lond B, 350, 243-251.

Renfree, M., Shaw, G., Clark, J., Short, R. \& Kerr, J. (1992a) Morphology of the developing urogenital system of the tammar wallaby, Macropus eugenii. $J$ Reprod Fert Abstr Ser, 9, 134. 
Renfree, M., Short, R., Shaw, G. \& O, W.-S. (1996) Sexual differentiation of the urogenital system of the fetal and neonatal tammar wallaby, Macropus eugenii. Anat Embryol, 194, 111-134.

Renfree, M., Wilson, J., Short, R., Shaw, G. \& George, F. (1992b) Steroid hormone content of the gonads of the Tammar Wallaby during sexual differentiation. Biol Reprod, 47, 644-647.

Renfree, M. B., Pask, A. J. \& Shaw, G. (2006) Sexual development of a model marsupial male. Aust J Zool., 54, 151-158.

Shaw, G., Renfree, M. B., Leihy, M. W., Shackleton, C. H., Roitman, E. \& Wilson, J. D. (2000) Prostate formation in a marsupial is mediated by the testicular androgen 5 alpha-androstane-3 alpha, 17 beta-diol. Proc Natl Acad Sci U S A, 97, 12256-9.

Silva, M. A. \& Merzel, J. (2001) Stereological determination of the volume of the rat hemimandible tissues. Anat Rec, 263, 255-9.

Sinha, A., Erickson, A. \& Seal, U. (1977) Fine structure of Leydig cells in crabeater, leopard and Ross seals. J Reprod Fertil, 49, 51-54.

Taggart, D., Johnson, J. \& Temple-Smith, P. (1993) Testicular and epididymal development in the brown marsupial mouse, Antechinus stuartii (Dasyuridae, Marsupialia). Anat Embryol, 188, 87-100.

Tahka, K. (1988) Effect of differential photoperiod treatment on Leydig cell ultrastructure in the bank vole (Clethrionomys glareolus, S.). Gen Comp Endocrinol, 71, 318-330.

Ullmann, S. (1981) Sexual differentiation of the gonads in bandicoots (Peramelidae, Marsupialia). In Byskov, A. \& Peters, H. (Eds.) Development and Function of Reproductive Organs. Amsterdam, Elsevier North-Holland.

Ullmann, S. (1984) Early differentiation of the testis in the native cat, Dasyurus viverrinus (Marsupialia. J Anat, 138, 675-688.

Ullmann, S. (1993) Differentiation of the gonads and initiation of mammary galand and scrotum development in the brushtail possum Trichosurus vulpecula (Marsupialia). Anat Embryol, 187, 475-484.

Van Vorstenbosch, C., Colenbrander, B. \& Wensing, C. (1984) Leydig cell development in the pig testis during the late fetal and early postnatal period: an electron microscopic study with attention to the influence of fetal decapitation. Am J Anat, 169, 121-136.

Williamson, P., Fletcher, T. P. \& Renfree, M. B. (1990) Testicular development and maturation of the hypothalamic-pituitary-testicular axis in the male tammar, Macropus eugenii. J Reprod Fertil, 88, 549-557.

Wilson, J. D., George, F. W., Shaw, G. \& Renfree, M. B. (1999) Virilization of the male pouch young of the tammar wallaby does not appear to be mediated by plasma testosterone or dihydrotestosterone. Biol Reprod, 61, 471-5.

Wilson, J. D., Leihy, M. W., Shaw, G. \& Renfree, M. B. (2003) Unsolved problems in male physiology: studies in a marsupial. Mol Cell Endocrinol, 211, 33-6.

Wing, T.-Y. \& Lin, H.-S. (1977) The fine structure of testicular interstitial cells in the adult Golden hamster with special reference to seasonal changes. Cell Tiss Res, 183, 385-393.

Xie, Q., Mackay, S., Ullmann, S., Gilmore, D. \& Payne, A. (1996) Testis development in the opossum Monodelphis domestica. J Anat, 189, 393-406.

Zirkin, B., Ewing, L., Kromann, N. \& Cochran, R. (1980) Testosterone secretion by rat, rabbit, guinea pig, dog, and hamster testes perfused in vitro: correlation with Leydig cell ultrastructure. Endocrinology, 107, 1867-1874. 


\section{Figure Legends}

Figure 1. a) Electron micrographs of testis at day of birth. Seminiferous cords (sc) have formed with enclosed germ cells (gc). Small groups of dark-staining undifferentiated mesenchymal cells $(\mathrm{m})$ can be seen in the interstitium. x1200 b) Testis at day 2 after birth. Tubule formation has continued and the tunica albuginea (ta) has formed. x1200 c) Interstitial tissue at day 2 after birth. Groups of Leydig cells can be seen with prominent lipid inclusions (arrows). There is still much extracellular space. $x 1650$ d) Day 2 presumptive Leydig cell. Note the close association of rough endoplasmic reticulum and mitochondria. The cytoplasm is highly granular and electron dense.

Figure 2. a) Interstium of day 6 testis. Leydig cells (L) have increased in number. There are still many undifferentiated cells (m). x2200 b) Cytoplasm of day 6 Leydig cell.Typical organelles of steroid producing cells are present. Note the mitochondria with tubular cristae (mi), smooth endoplasmic reticulum (SER), vesicles (v) and prominent lipid droplets (li). There is a strong association of rough endoplasmic reticulum and mitochondria which produce an annular profile in cross section (arrow). The plasmalemma is extended into long filopodial extensions (arrowhead). x8900 c) Interstitial tissue of a day 10 testis. Leydig cells (L) have increased in number and are arranged in groups. Note the interdigitations in the Leydig cell membranes. x2200 d) Differentiated Leydig cell at day 10 after birth. Note abundant mitochondria (mi), and well developed smooth endoplasmic reticulum and numerous vesicles (SER). There is little lipid present in these cells. x5200

Figure 3. a) Detail of Leydig cell from day 21 testis. Well developed Golgi apparatus - appearing as vesicles in cross-section - are present in association with SER. b) Leydig cell day 21 after birth. Note long filopodial extensions from adjacent cells 
wrapped around this cell. c) Leydig cell day 30 after birth. The extensive SER is arranged in concentric layers in the cytoplasm with abundant mitochondria. d) Leydig cell day 54 after birth. Note extracellular collagen fibres.

Figure 4. a) The Leydig cell at day 100 after birth. The cytoplasm is tightly packed with parallel whorls of smooth endoplasmic reticulum in around the mitochondria. x28,500. b) Leydig cells day 275 after birth. SER is well developed and lipid droplets (Li) are prominent in the cytoplasm. Note the microvillae on the plasma membrane (arrowhead). x2950. c) Cytoplasm of Leydig cell at day 275. Note the well developed parallel arrays of SER and mitochondria with tubular cristae. $\mathrm{Li}=$ lipid droplets $\mathbf{d}$ ) Leydig cell at 13 months p.p. Similar to post day 60 Leydig cells. Note the prominent lipid droplets in the cytoplasm (li).

Figure 5. a) Leydig cell at 24 months. This animal has mature sperm in the testicular tubules (not shown) and the Leydig cell has an adult appearance with abundant mitochondria, well-developed anastomosing SER and few lipid droplets. b) Adult Leydig cell. There is a prominent round nucleus and extensive cytoplasm tightly packed with SER. Lipid is only occasionally present (arrowhead). Note the interdigitating cell membranes (arrow).

Figure 6. Post-natal growth of the tammar testis between day 10 and day 100. Log of testis volume is plotted against age (days after birth). The growth of the testis is exponential but after day 100 the rate changes as indicated by the slopes of the lines of best fit. Data points represent individual testes.

Figure 7. Percentage volume of cell types in the testis over time. Data were taken at set time points: a) day $10(n=2)$, b) day $30(n=4)$, c) day $60(n=3), d)$ day $100(n=2), e)$ 
13 months $(n=2)$ and f) 24 months $(n=2)$. Representative light micrographs for each age are below the graphs, scale bar $=100 \mu \mathrm{m}$.

Figure 8. Electron micrographs of tight junctions in the tammar testis. Tight junctions between the cell membranes of Sertoli cells are marked by an arrow. Boxed area is enlarged on the right. The earliest tight junctions were seen was at day 31 .

Figure 9. Relation of Leydig cell development to testosterone content of the tammar testis. Leydig cells are initially marked by the development of lipid droplets which are lost as the testis matures and androgen content increases, reflecting a mature steroid synthesis pathway. As androgen content drops away before puberty lipid reappears in the cytoplasm. After puberty testosterone content increases dramatically (not shown) and Leydig cells take on their final, adult, appearance. Drawings of Leydig cell cytology (left to right) days 2, 10, 60 and adult. Testosterone content redrawn from Renfree et al., (1992). 

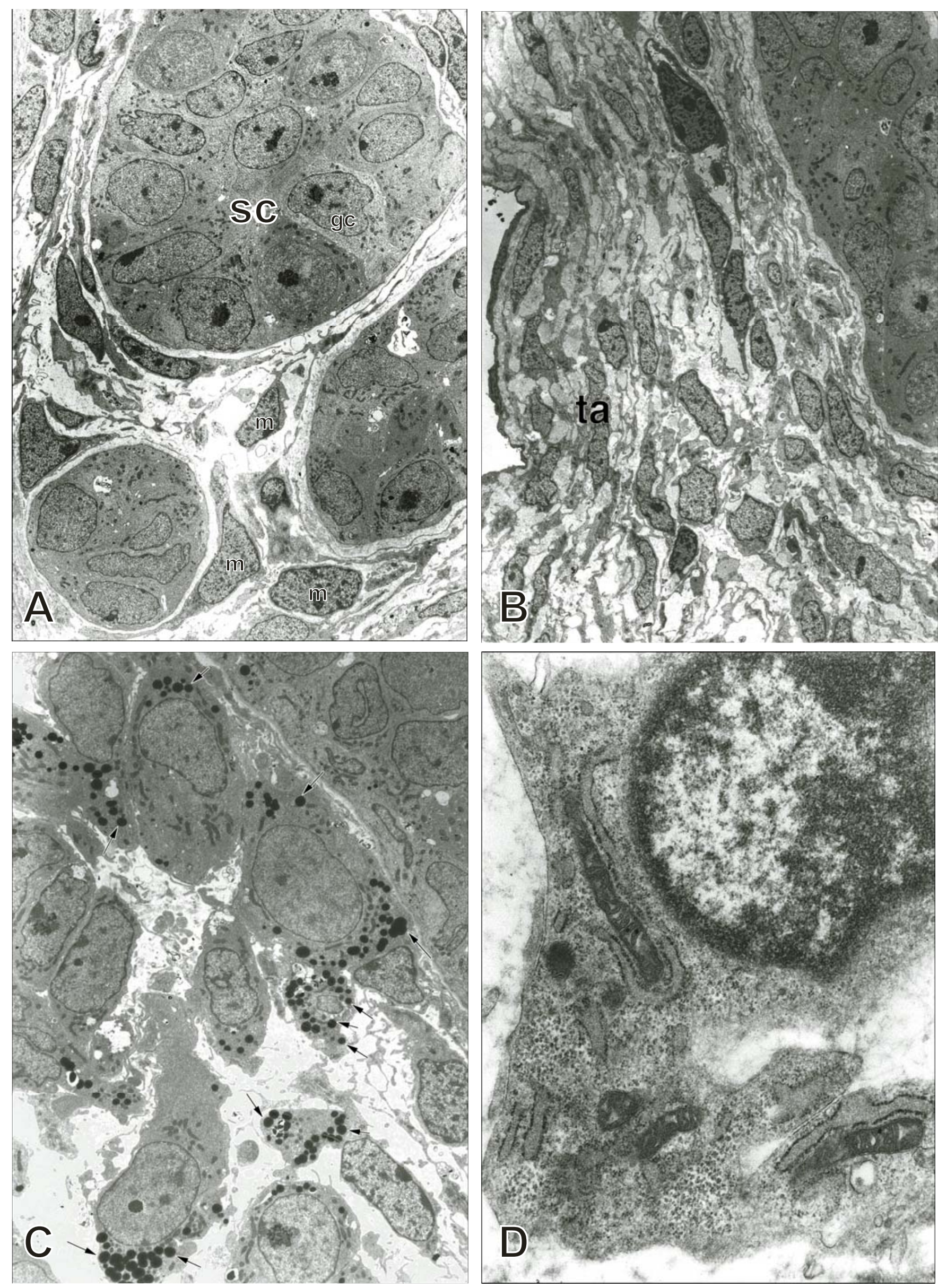

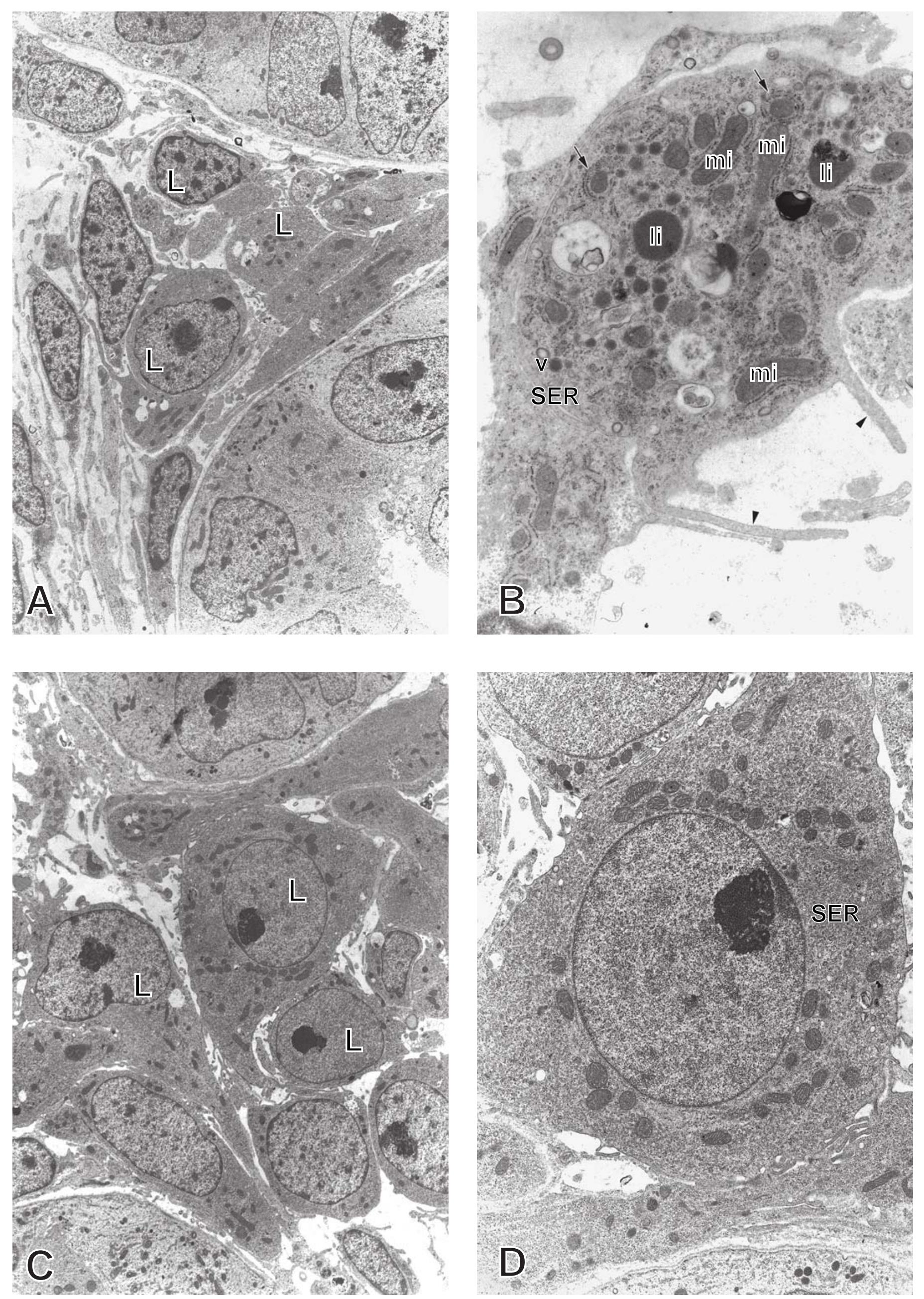
Figure 3
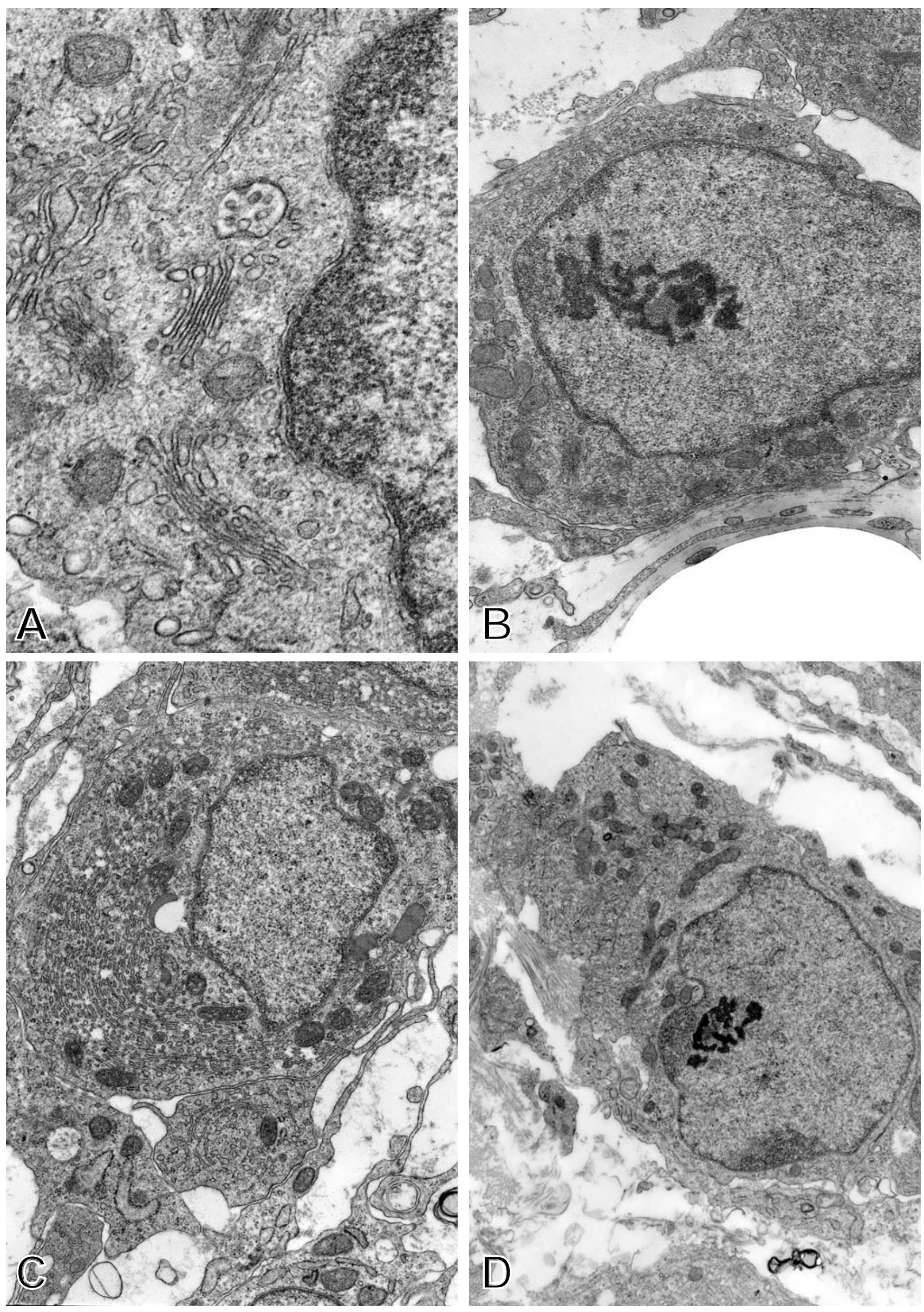

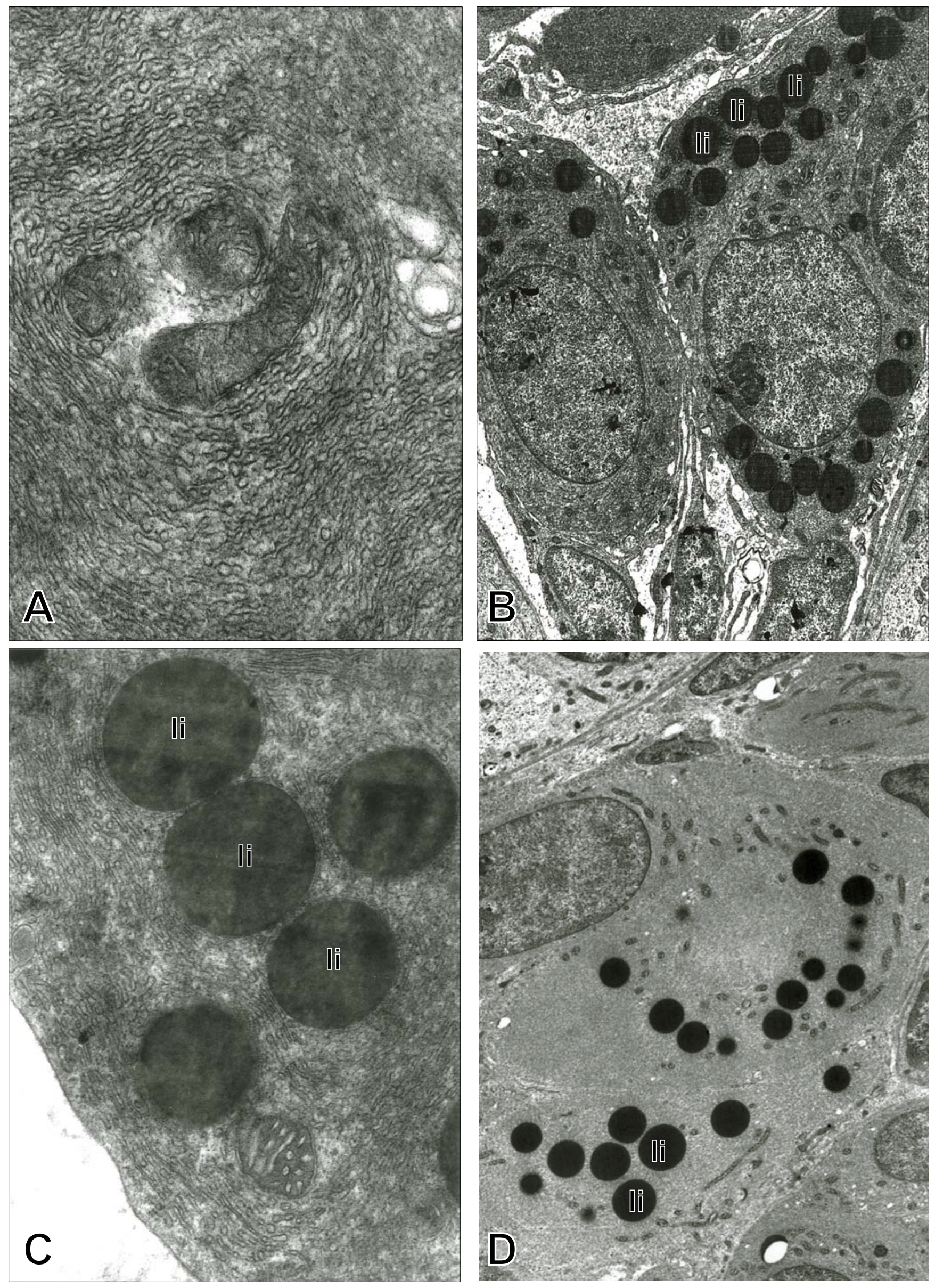

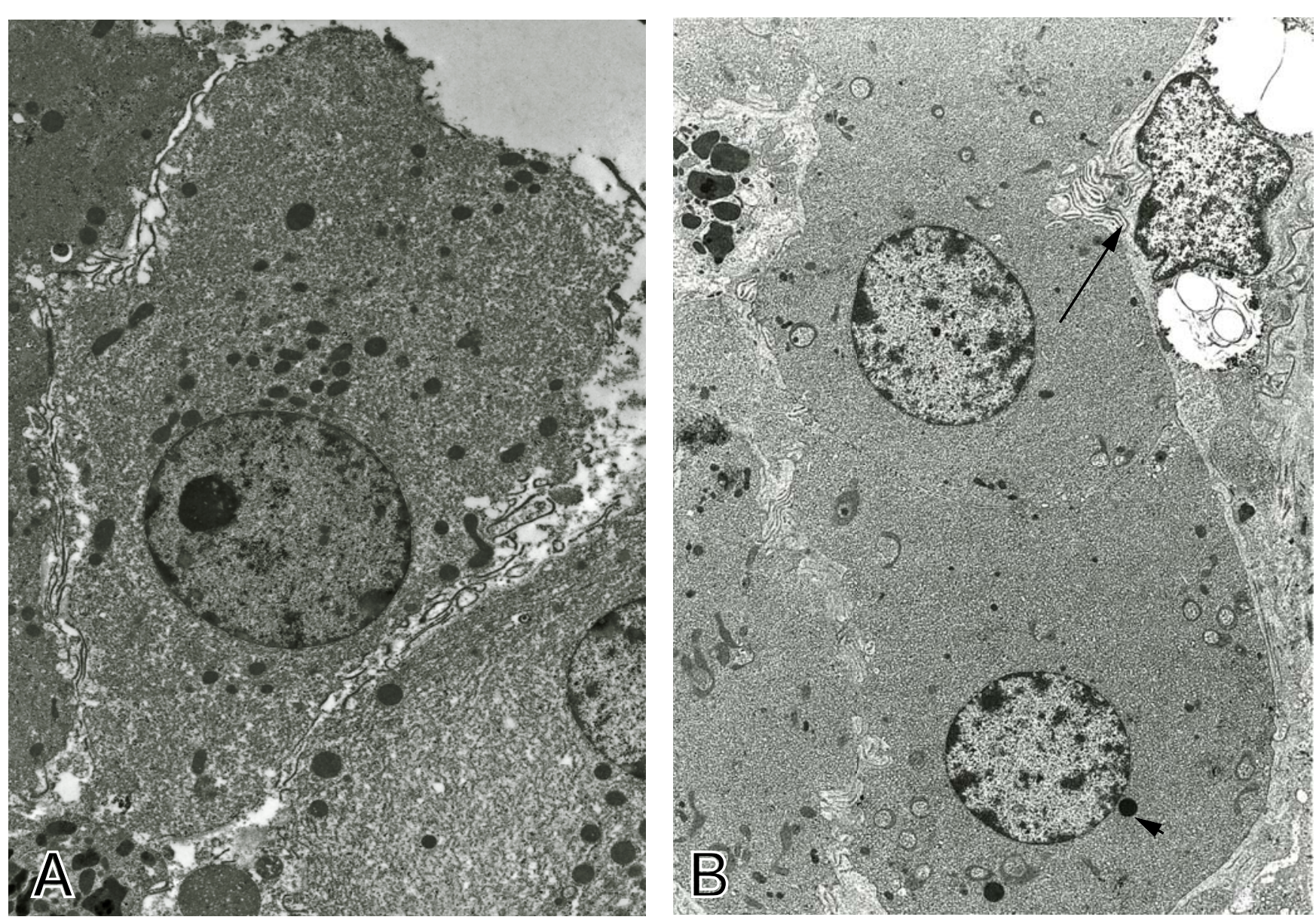
FIgure 6

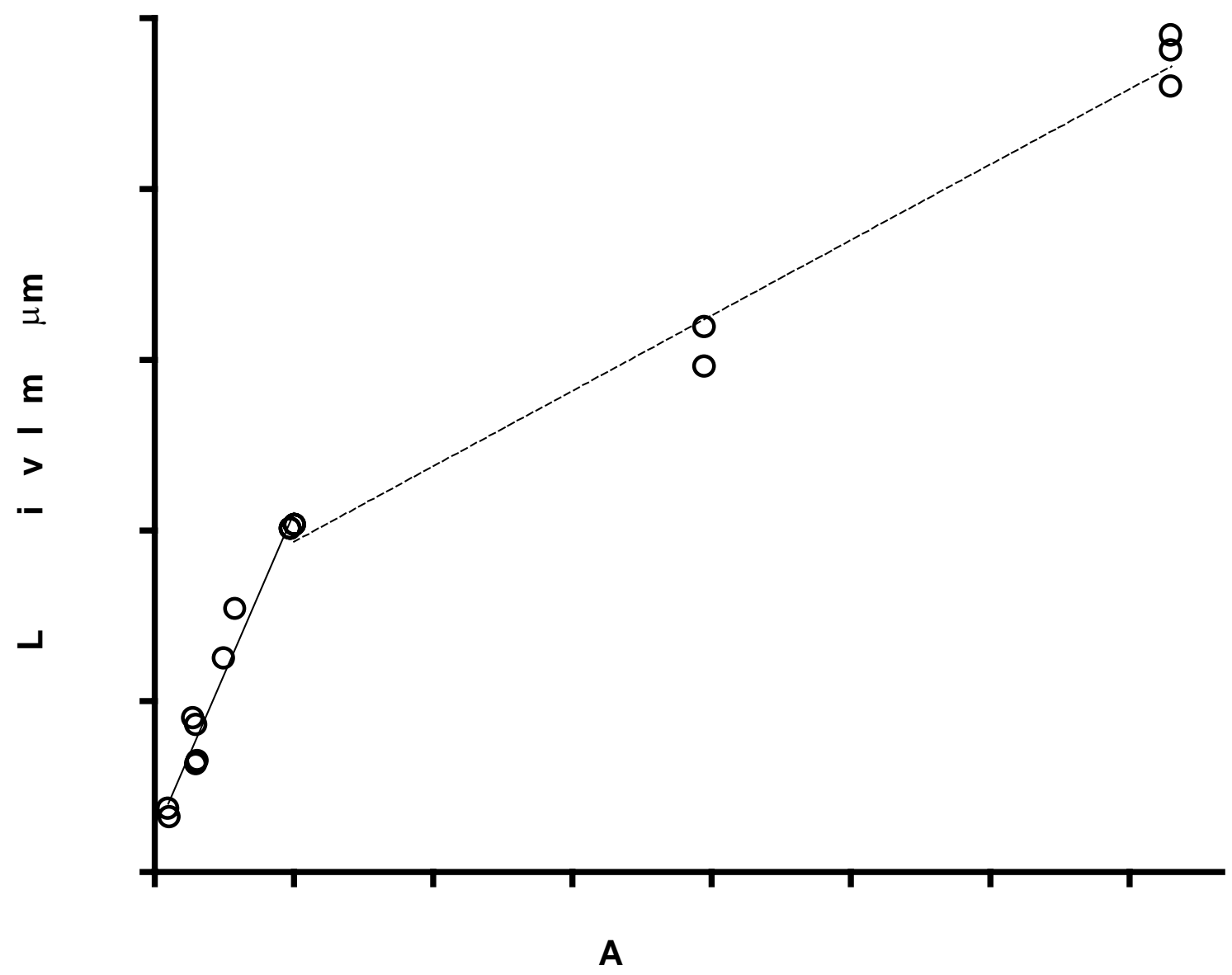



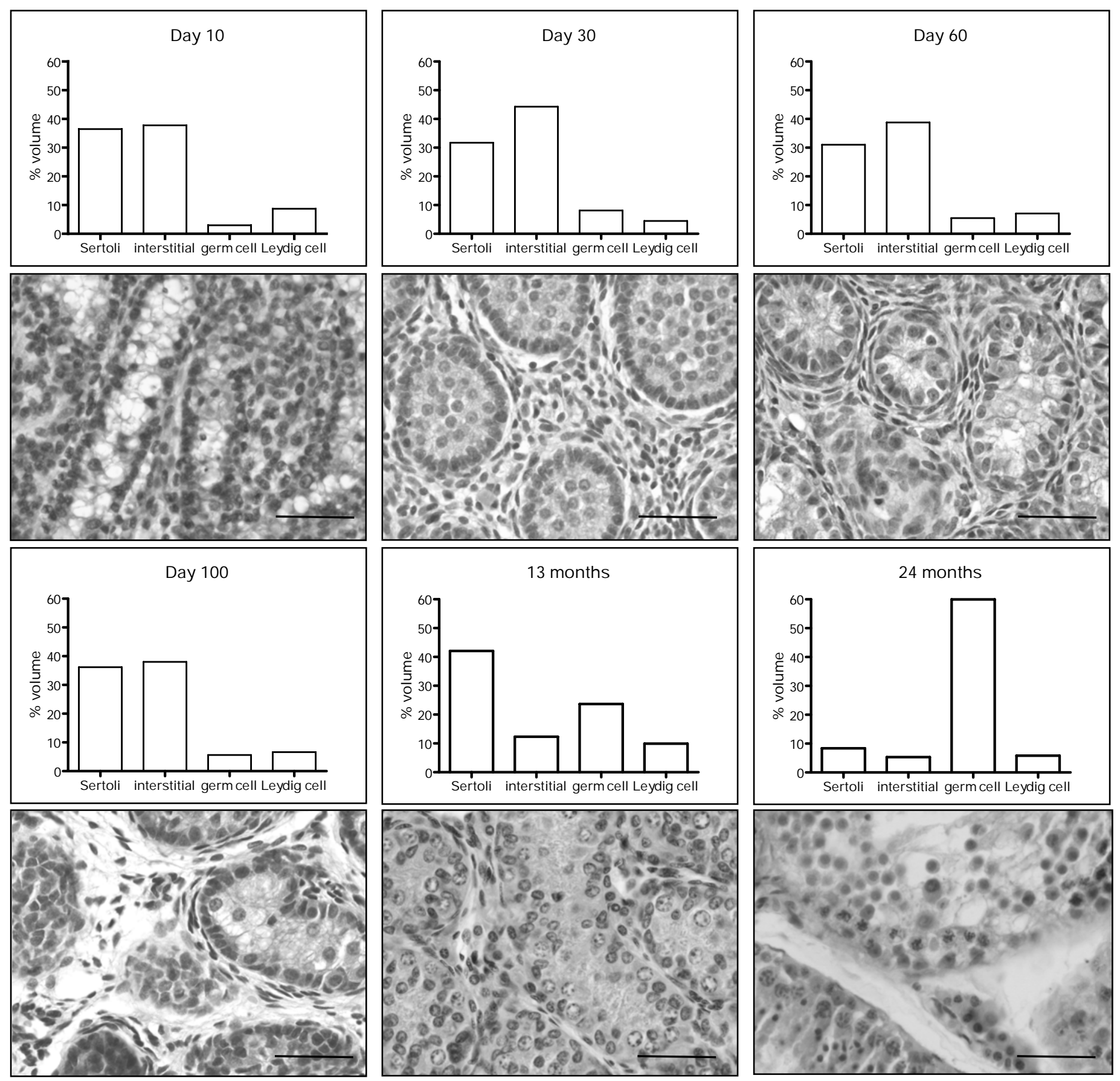

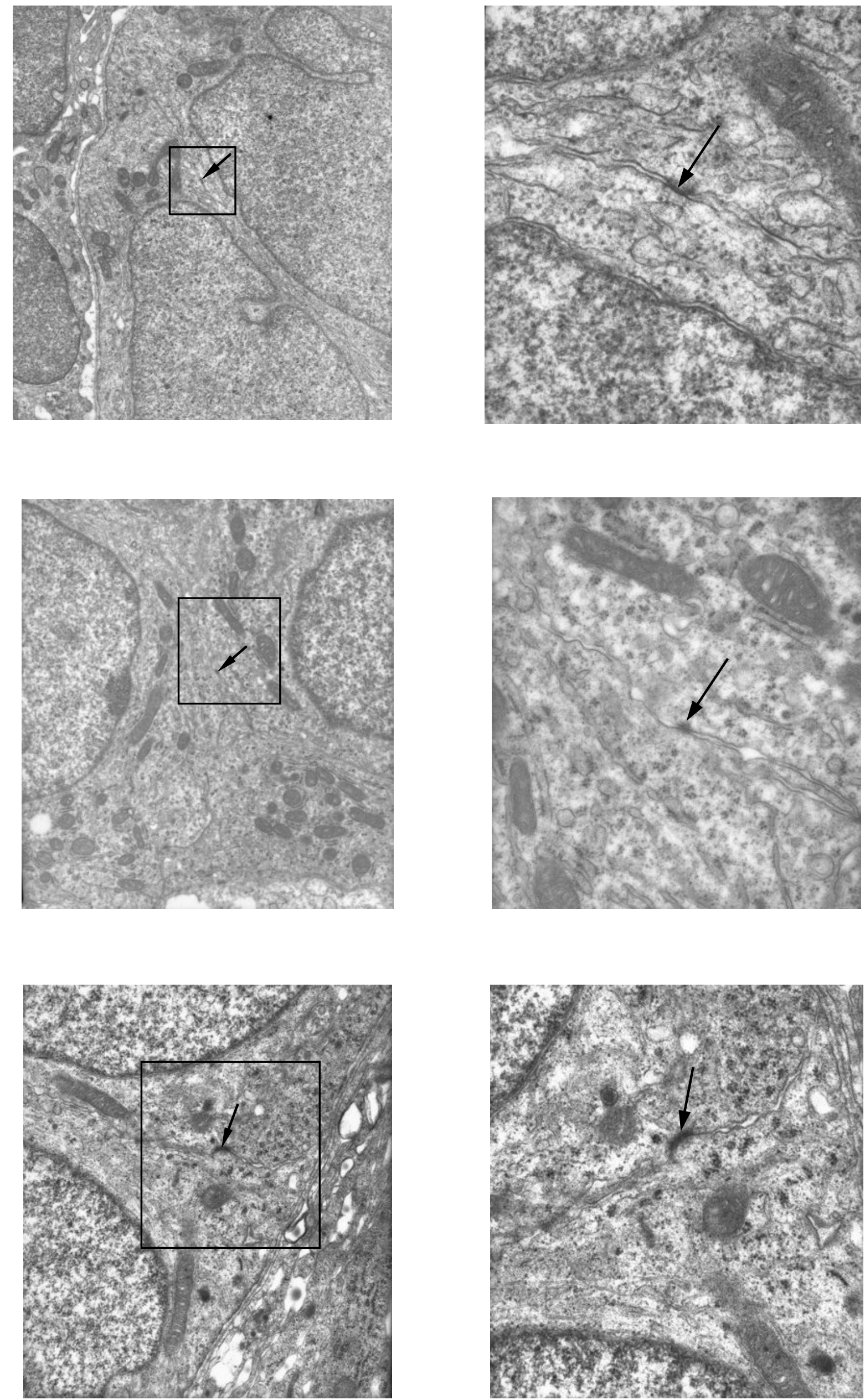


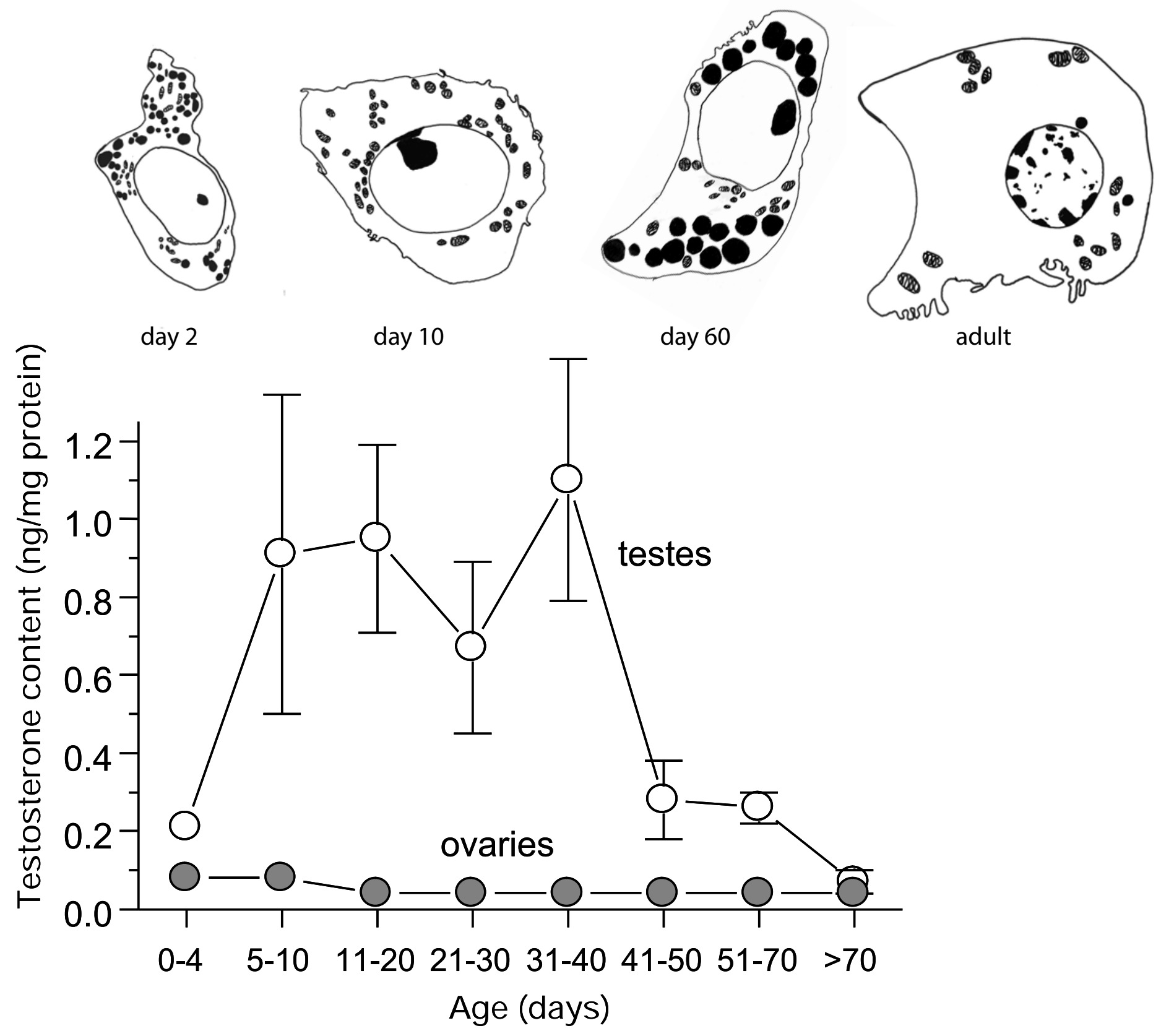




\section{University Library}

\section{- M M I N E R VA A gateway to Melbourne's research publications}

Minerva Access is the Institutional Repository of The University of Melbourne

Author/s:

Butler, CM;Shaw, G;Clark, J;Renfree, MB

Title:

The functional development of Leydig cells in a marsupial

Date:

2008-01-01

Citation:

Butler, C. M., Shaw, G., Clark, J. \& Renfree, M. B. (2008). The functional development of Leydig cells in a marsupial. JOURNAL OF ANATOMY, 212 (1), pp.55-66. https:// doi.org/10.1111/j.1469-7580.2007.00837.x.

Publication Status:

Inpress

Persistent Link:

http://hdl.handle.net/11343/34769 